\title{
Model of Learning Information and Communication Technology based; Study of Learning Islamic Educationat Senior High School 4 Kendari
}

\author{
Zulkifli.M \\ Sekolah Tinggi Agama Islam Negeri Kendari,Indonesia
}

\begin{abstract}
The aim of this research is to produce a model of Learning Islamic Education (LIE/PAI) information and communication technology based that is valid, practical and effective in Senior High School (SHS/SMA) 4 Kendari. This research using a method of research and development in education. This research concludes that results validation book model of PAI, the syllabus, Implementation Plan of Learning (RPP), PAI material for teachers and students, slide presentation, Student worksheet (SW/LKS), instructions using a model (teachers and students) and evaluation of study result of the obtained average value of over 3 that meant something very valid. In the II trial against components of syntax direct teaching, social interactions/socialsystem and principle reaction indicates that the components of the fulfillment of the system entirely except for supporting a device of learning. Learning management in class on trial II show that any preliminary activity of learning core, activities, activity covering/end, and the whole class accomplished with a rate reached 3.21 . In on it, the results also indicated that there are differences achievement learning PAI information and communication technology based significantly between trial I with the trial II against graders XI Natural Science (NS/IPA) and social studies (SS/IPS).
\end{abstract}

Keywords: Model of Learning, Information and Communication Technology

\section{Introduction}

Education is basically an effort to develop the potential self through develop their talent or potential toward better and development potential and aptitude through a process of learning which are expected to expand participants potential in learning process by use the media in the form of equipment in the field of information and communication technology(Barizi and Idris, 2009; Suparno, 2000).

The development of information technology in recently very rapidly and encouraging the emergence of a new paradigm of society to get information through print and electronic media, as well as other information sources such as information from cyberspace (Miarso,2008; Mukhtar and Iskandar, 2010). One of the areas that get appreciable impact in the development of research and technology is education(Asmani, 2011; Lincoln et al., 1985) Information technology is not only become information accessible any time, but also to an accessible person by information(Rose and Nicholl, 2009). Diversion information from physical media to digital media now enables information accessible through electronic means.

Information and communication technology has three major functions; first, Creating conditions learning fun and piquant (effect emotion). Second; equip students with skills for using high-tech. Third; Technology serve as learning tools with programs, application and utilities that in addition to simplify and speed things up, will multiply variation and techniques of the analysis and interpretation (Mukhtar and Iskandar, 2010; Rose and Nicholl, 2009)

\subsection{Learning}

\section{Theoretical Framework}

Learning (instruction) is an attempt to make the learners learn or an activity to teach learners. In another sense, learning is a planned efforts in manipulating sources of learning so that the learning process occurs inside of the learners (Sadiman, 1986). Learning is a process, a way, making people or living beings learn (Barizi,. and Idris, 2009).

Therefore, there are five types of interactions that can take place in the process of learning and teaching, namely: (1). Interaction between educators and learners; (2). Interaction between fellow learners; (3). Interaction between fellow learners with guest speakers; (4). Learner interactions with educators with a learning resource that is intentionally developed; and (5). Learner interactions with educators with the social environment and nature (Miarso, 2008)

There are 3 (three) in teaching theory, i.e., Behaviorism, constructivism, and cognitivist. Mayer proposes another term from all three above mentioned learning theory in order to be easily understood, namely: 
(a) Mastery Learning as a response (Behaviorism); b) learning as knowledge mastery (cognitivist); and c) learning as knowledge construction (constructivism) (Shambaugh and Susan, 2006).

\subsection{Development of Learning Model}

Terms of the development of a learning program, namely: (1) Allow learners experiencing learning processes that are relevant to the purpose to be achieved; (2) can choose materials and learning resources; (3) should be able to select and develop the learning media can support further understand a concept; (4) should devise a model learning interactions that challenge learners to think and contemplate; and (5) designing a program evaluation(Sudjiarto, 1994).

\subsection{Development of Learning Model}

Development is the process of translating specifications design into a form certain physical. In one piece, learning activities require design to direction and learning activities can reach its destination expected. Design process starts from identification problem or identification necessity of learning and ended by identification materials and strategy of learning, while the process of development started from choose or develop material learning and pouring it in strategy learning designed, then ended by evaluate strategy following material learning the to improve effectiveness and their efficiency (Seels and Rickey, 1994).

\subsection{Learning model for LIE/PAI ICT Based}

Assessment of the quality of teaching models include (a) the validity; and (b) practicality. To assess the validity of the models used two criteria, namely: (a) the model developed is based on a strong theoretical rationale and (b) the model has the consistency of internally. There are two models of the practicality criteria, namely (a) the model developed can be applied according to the assessment of the experts or practitioners and (b) the model developed can be applied in real terms in the field (Nieveen, 1999).

\section{Methodology}

This research use qualitative approach that describe model of learning Islamic education information and communication technology based at SHS 4 Kendari.

\subsection{Research steps}

First; DataCollecting /information related theory, observation in a classroom, and prepare research report. second; defining skill, setting activities steps, and test probability scale at low level. Third;developing instruction material and book, and setting evaluation. Forth; testing setting/preliminary research that is testing product at school using $6-12$ subject. Fifth; revise product using testing result of preliminary research. Sixth; testing product at school using $25-30$ subject. Seventh; revise operational product by core testing result. Eighth; testing of operational field in $10-30$ schools include $40-200$ subject by collecting and analyze interview result, observation and questionnaire. Ninth; revise final product base on field operational of results. Tenth; dissemination and distribution of the report the study results in the journal and meetings in collaboration with publishers who can distribute the results commercially. Oversee distribution in order to remain in control and quality (Borg, 1981).

\subsection{Design testing and product development}

The trial is part of the most important in order for the resulting application deserves to be used(Dick et al., 2005;Faisal, 1990; Gustapon and Branch, 2002). Its steps: (1).Validation material experts, expert learning media and information and Communication Technology Experts (ICT); (2).Conceptual analysis; (3) Revision development based on judgment experts on stage one form of input criticism or expert advice matter, media experts, the information technology and communication (ICT) then repairing; (4).Trial against peers group (teachers PAI) and (one-on-one and small groups); (5) Conceptual and product analysis; (6) Product revise (Step 2); (7) trial against students; (8). Students feedback on product effectiveness;(9). Empirical analysis (Step 3); (10).Minor revise; and (11). Final product of development that is conceptual model, procedural model and physical model.

At this stage the generated prototype 1 (early) as a result of realization of content design learning device, thus is generated the development of Islamic education (LIE/PAI) ICT based/e-learning that consists of: (1) the validity of a learning model development sheet; (2) acceptance of the model development sheet; (3) the observation Sheet for implementation of learning model development; (4) the observation Sheet the teacher's ability to manage learning; (5) student activity sheets; (6) a completed student response; (7) the teacher performance assessment Instruments.

Technique analysis of data are; validity, implementation of device learning LIE/PAI ICT based /e- 
learning; ability teacher in the management of learning LIE/PAI based ICT based/e-learning, activity students learning against LIE/PAI ICT based /e-learning; a response students toward learning; performance appraisal teacher $(\mathrm{PAT} / \mathrm{PKG})$ in learning process, and analysis of the study result.

\subsection{Understanding students against ICT Based learning}

\section{Discussion}

Based on the results of the survey and interview conducted in SHS 4 kendari obtained information that lesson for islamic education (LIE/PAI) especially aspects al-quran still elusive by student XI-1 Class (IPA-IPS) and the teacher LIE/PAI class xi-1 not apply a model of ICT Based learning especially for moodle program. The tracing further information through survey about need assessment against school, teachers and students SHS 4 kendari with ask some questions obtained information that students and teacher need to implement e-learning at SHS 4 kendari

Design model in book form model containing elaborated things pertaining to the fundamental theories for learning model of LIE/PAI with information and communication technology based, syntax learning LIE/PAI, social system, principle reaction (behavior teacher), support system, instructional impact, and counterpoint the learning, learning environment and duties management, and evaluation

The design model of LIE/PAI learning device can be explained as follows: (1). The syllabus LIE/PAI class XI-1; (2) LIE/PAI subject ( handbook teachers and students book); (3). Implementation plan of learning (IPL/RPP); (4). A students activities sheet (LKS); (5). A slide presentation of LIE/PAI Subject; (6). A clue the use of moodle (teachers and students); (7). Appraisement/evaluation

\subsection{Product Validation Test.}

Test validation referred to is: a ) validation book model; b ) validation syllabus LIE/PAI; c ) validation of subject ILE/PAI (handbook teachers and students ); d ) Implementation of learning Plan (draft ); e ) students worksheet (LKS); f ) slide presentation; g ) media ICT; h). design learning; i) judgment / evaluation of the results of study.

The result of validation book model LIE/PAI reach on average 3,84 that meant is very valid. Validation of the syllabus reach on average 3,82 that meant very valid, RPP is average 3.79 very valid, LIE/PAI Subject for teachers and students 3,62 very valid, the average slide presentation 3,80 very valid, the average of LKS is 3,77 very valid, Instruction of the use of moodle ( teachers and students ) is average 3,36 valid and evaluation of result of the study is average 3,81 very valid.

\subsection{Analysis of learning model LIE/PAIICT based at testing 1 class XI Social science 2.}

The main goal of data analysis of practicability (Implementation) LIE/PAI model of trial results I is to explain the level of practicality model LIE/PAI-TIK. Observation data of implementation of LIE/PAI model ICT based analyzed in each component of model.

The result analysis to each component as follows: (1) the components of directly syntax teaching average 2.54 means done entirely; (2) Social interactions/system social average 2.26 means accomplished largely; (3) the principle reaction average 2.59 means done entirely; (4) the support system device learning average 2.81 means done entirely.

So in all practicability model LIE/PAI -TIK reach on average 2.55 which means done entirely. Management of learning in classes on trial I can be explained as follows: (1). In any preliminary activity reach on average 2.96 which means done entirely; (2). Core activities reach on average 2.80 which means done entirely; (3). End activities reach on average 2.75 which means done entirely; (4). The class atmosphere reach on average 3,63 which means done entirely. So, the overall management of the learning on a test I reached an average of 2.96 meaning done entirely.

\subsection{Analysis of practicability of LIE/PAI Model ICT-based on test II class XIIA-1}

The result analysis to each component model LIE/PAI ICT on trial II can be described as follows: (1) component syntax of direct teaching is average 2.52 means operate entirely; (2) Social interactions /Social systems is average 2.17 means accomplished largely; (3) the principle reaction is average 2.55 means operate entirely; (4) the support system learning device is average 2.69 means operate entirely. So overall reach on average 2.48 means accomplished largely.

Management of learning in class II tests can be presented as follows: (1). Early learning activities on achieving an average 3.25 means carried out entirely; (2) core activities to achieve an average of 3.16 means carried out entirely; (3) Closing activities achieved an average 2.75 means carried out entirely; (4) a class reaches an average of 3.69 means carried out entirely. So the overall management of the learning trials II reached 3.21 means carried out entirely. 


\subsection{Conclusion}

\section{Conclusion and Suggestion}

The results achieved through the process of testing the model is as follows:

1. Results are achieved in test I class XI IS-2, namely (1) models of LIE/PAI-ICT had practically reached the average 2.55 which means carried out entirely; (2) the management of learning LIE/PAI-ICT also had practical i.e. reach an average of 2.96 meaning done entirely.

2. The results achieved in test II Class XI IA-1, namely (1) models of ICT-PIE has been practically i.e. achieved an average of 2.48 means carried out entirely; (2) the management of learning ICT-PIE also had practical i.e. reach an average 3.21 meaning done entirely. If compared between experimental I PAI-models of ICT with a test run to the II class XI class XI IS the SCIENCE of IPS with apparently increased significantly

\subsection{Suggestion}

1. This research has produced LIE/PAI learning model ICT-based is valid and practical. It is therefore suggested to the teacher of LIE/PAI to implement this model on a wider scope both in terms of content and in terms of the types and levels of education.

2. To implementation widely, teacher of LIE/PAI expected to develop own devices of learning (Implementation Plan of Learning (RPP), book students, Students worksheet, slide presentation of LIE/PAI subject) corresponding to characteristics and components model LIE/PAI ICT based;

[1] Asmani, J.M. (2011). Tips Efektif Pemanfaatan Teknologi Informasi dan Komunikasi Dalam Dunia Pendidikan. Yogyakarta: DIVA press.

[2] Barizi,A. and Idris.M. (2009). Menjadi Guru Unggul Bagaimana Menciptakan Pembelajaran yangProduktif dan Profesional. Yogyakarta: Ar-Ruzz Media.

[3] Borg, Walter R. (1981). Applying Educational Research A Practical Guide for Teachers. New York \& London: Longman Inc.

[4] Depdiknas. (2003). Undang-Undang Republik Indonesia Nomor 20 Tahun 2003 tentang Sistem Pendidikan Nasional. Jakarta: Biro Hukum dan Organisasi Depdiknas.

[5] Dick, Walter., Carey, Lou. \& Carey, James O. (2005). The Systematic Design Of Instruction (6 ${ }^{\text {th }}$ ed.). Boston, Pearson

[6] Dryden,Gordon and Vos, Jeannette. (2002). Revolusi Cara Belajar The Learning Revolution. Bandung: Kaifa

[7] Faisal, Sanafiah. (1990). Penelitian Kualitatif, Dasar-Dasar Aplikasi, Yayasan Asih Asuh. Malang.

[8] Gustapson, Kent L. and Branch, Robert Maribe. (2002). Survei of Instructional Development Models. New York, Eric Clearinghouse on Information \& T e chnolog y S y racus e University.

[9] Joyce, Bruce(2009). Models of Teaching Model-Model Pengajaran. Yogyakarta: Pustaka Pelajar.

[10] Lincoln,Yvon Lis and Egon G. Guba. (1985).Naturalistic Inquiry. Beverly Hills.Sage Publications. Bandung.

[11] Miarso, Yusufhadi. (2004). Menyemai Benih Teknologi Pendidikan. Jakarta: Prenada Media.

[12] ............ (2008). Penerapan Teknologi Informasi dan Komunikasi Dalam Pendidikan di Era Globalisasi. Jakarta: Makalah Seminar Nasional The Power of ICT in Education, PPs UNJ, 15 April 2008.

[13] Mukhtar and Iskandar. (2010). Desain Pembelajaran Berbasis Teknologi Informasi dan Komunikasi (Sebuah Orientasi Baru). Jakarta: Gaung Persada Press

[14] Munir. (2009). Pembelajaran Jarak Jauh Berbasis TIK. Bandung : Alfabeta.

[15] Nasution. (1988). Metode Naturalistik Kualitatif. Tarsito. Bandung

[16] Nieveen, Nienke. (1999). Prototyping to Reach Product Quality. In Jan Van den Akker, R.M. Branch, K. Gustafson, N. Nieveen, and Tj. Plomp. Design Approaches and Tools in Education and Training. Dordrecht, The Netherlands: Kluwer Academic Publisher.

[17] Pribadi, Benny A. (2011). Model ASSURE untuk Mendesain Pembelajaran Sukses. Jakarta: Dian Rakyat.

[18] Robbins, Stephen P. (1996). Organizational B e havior: Concepts, Controversies, Applications (7 $7^{\text {th }}$ Ed.). Prentice-Hall International, Inc.

[19] Rose, Colin and Nicholl,M. (2009). Accelerated Learning. Bandung: Nuansa

[20] Sadiman, Arief (1986). Media Pendidikan, Pengertian, Pengembangan, dan Pemanfatannya. Jakarta: Rajawali.

[21] Seels, Barbara B. and Rickey, Rita C. (1994). Instructional Technology: The Definition and Domain of the Field. Washington DC, Association for Educational Communication and Technology

[22] Shambaugh, Neal and Susan G.Magliaro. (2006). Instructional Design. United States of America:Lybrary of Congress Cataloging in Publication Data.

[23] Siahaan, Sudirman. (2008). Mengapa Harus Menggunakan E-Learning Dalam Keiatan Pembelajaran. Jurnal Teknodik Vol.XII. No.1. Jakarta: Depdiknas

[24] Sudijarto. (1994). Belajar dan Pembelajaran. Jakarta: Rineka Cipta.

[25] …......, (2010). Pengantar Ilmu Pendidikan. Makassar: Badan Penerbit UNM

[26] Suhartono, Suparlan. (2009). Filsafat Pendidikan. Makassar: Badan Penerbit UNM

[27] Suparno, Herawati. (2000). Aplikasi Pendekatan Konstruktivistik Dalam Pembelajaran IPA-Biologi Sekolah Menengah dan Pengaruhnya Terhadap Minat dan Motivasi Belajar Mahasiswa di Perguruan Tinggi. Makalah Seminar Nasional Makassar: Lembaga Penelitian UNM Makassar.

[28] Suryadi, Ace. (2007). Pemanfaatan ICT dalam Pembelajaran. Jurnal Pendidikan Terbuka dan Jarak Jauh. Vol.8 No,2.Jakarta: LPPM-Universitas Terbuka

[29] Syah, Muhibbin. (2000). Psikologi Pendidikan Dengan Pendekatan Baru. Bandung: PT.Remaja Rosdakarya.

[30] Syahidin. (2009). Menelusuri Metode Pendidikan Dalam Al-Qur'an. Bandung: Alfabeta. 